The species ranges through temerate eastern America from the outhern New England states south to Massachusetts and New York, west to Michigan, Wisconsin and Minnesota, orth to southwestern Quebec, and est to southcentral Manitoba. It ocurs in Saskatchewan as disjunct opulations.

It is hoped that this rare orchid will ot succumb to overzealous collectors $r$ vandalism. Although some efforts re being made to protect the species t Hudson Bays, the author strongly rges that all our native orchids be laced on the list of protected native flora soon before it is too late.

'BREITUNG, A. J. 1947. Catalogue of the Vascular Plants of Central Eastern Saskatchewan. Canadian Field Naturalist. 61(3):71. 100.

"CODY, W. J. 1973. Ram's-head Lady's-slipper Rediscovered in Saskatchewan. Blue Jay. $31(3): 180-181$.

"KENDREW, W. G. and B. W. CURRIE. 1955. The Climate of Central Canada. Queen's Printer, Ottawa.

†THOMAS, M. K. 1953. Climatological Atlas of Canada. Canada Department of Transport, Ottawa.

'V ANCE, F. R. 1973. Ram's-head Lady's-slipper at Hudson Bay, Saskatchewan. Blue Jay. $31(4): 249-250$.

\title{
THE ROLE OF NATURAL BIOLOGICAL AGENTS IN CONTROLLING A PINE STEM RUST (CRONARTIUM COMANDRAE)
}

\author{
by JOHN M. POWELL*
}

The stem or blister rust fungi are mong the most destructive and angerous diseases of pines. Six ecies of these rusts are found in anada, five of which occur in the airie Provinces. The best known is e introduced white pine blister rust hich attacks the five-needle or white nes. The others are native and occur the two-needle or hard pine group hich includes jackpine (Pinus inksiana Lamb.) and lodgepole pine

Northern Forest Research Centre,

inadian Forestry Service,

epartment of the Environment,

imonton, Alberta.
(P. contorta Dougl. var. latifolia Engelm.). One of the native rusts is the Comandra blister rust (Cronartium comandrae $\mathrm{Pk}$.) which is found across Canada ${ }^{1}$ and over much of the United States, and now has been reported infecting 15 species of pines in North America ${ }^{6}$. This rust has been the subject of a 6-year study carried out largely in southwestern Alberta where it occurs on lodgepole pine. One objective of the study was to assess the role of various biological agents, namely the macro- and micro-fauna and micro-flora, on the production of rust spores and whether rust cankers 


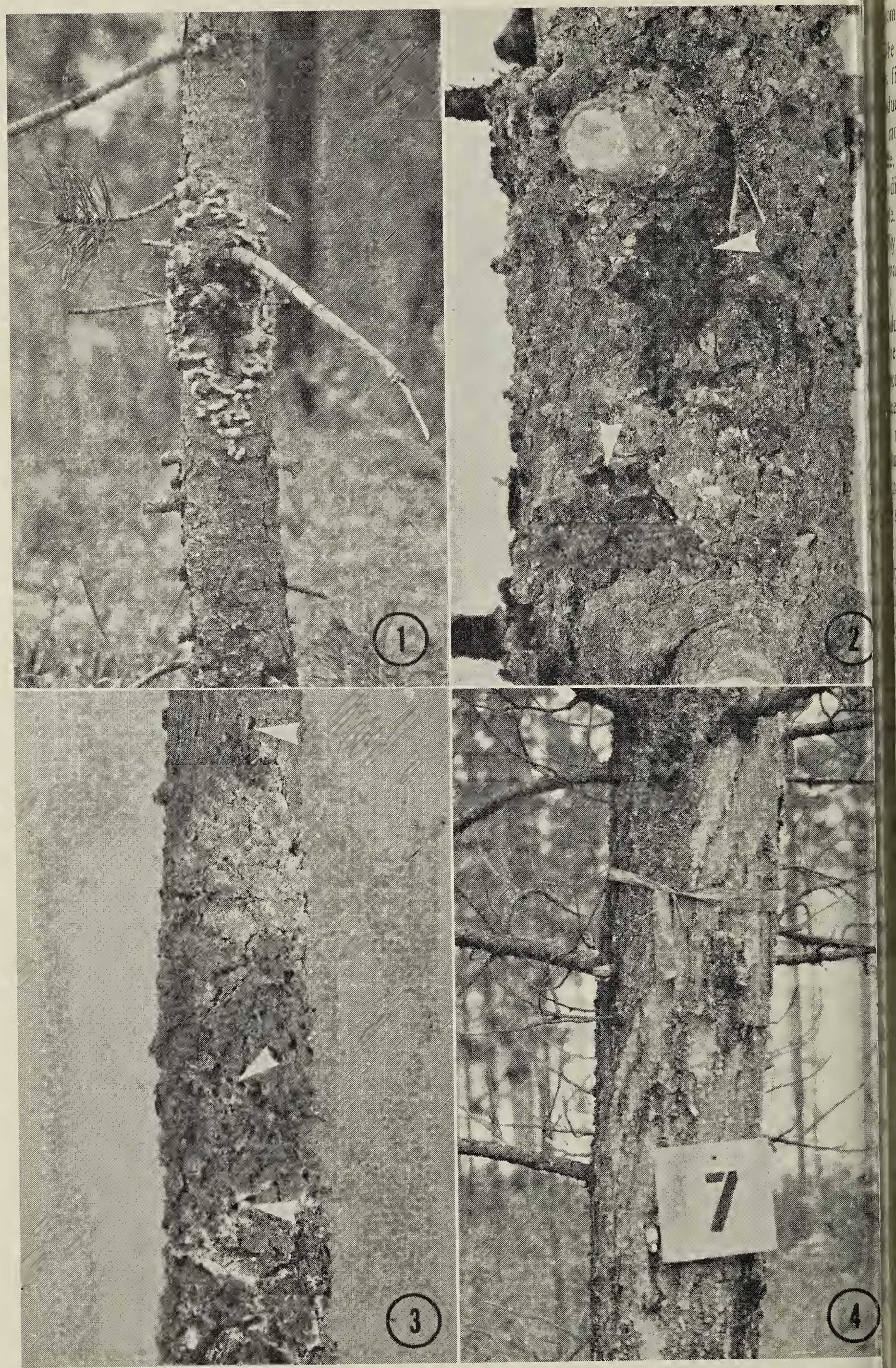

Figs. 1 to 4. Cankers of comandra blister rust on lodgepole pine. 
ay be inactivated through the action some of these biological agents.

The Comandra blister rust fungus s five spore forms which are oduced in succession and it takes 2 more years to complete its life cle, for, like most rusts, it requires o distinct host plants to complete its cle. The rust fungus grows perenilly in the living bark of pines, its imary host, and causes a swelling d canker. The rust annually oduces its spermogonial and aecial ore states along the edges of the nker (Fig. 1). The spermogonial ore state is the sexual spore stage of rust which produces masses of inute spores (called spermatia or cniospores). The spores exude from spermogonia (structures that bear sex organs) in orange gelatinous oplets in mid-or late summer. The cial spore state develops from miday to August on the same area of the rk where the spermogonia were oduced the previous year. The aecia blister-like fruiting bodies, which e the disease its name, push through bark tissues to rupture and release wdery masses of small, pear-shaped ange-yellow spores (aeciospores, g. 5) which are dispersed by the nd. These aeciospores may land on septible alternate hosts, i.e., the rennial herbs comandra or bastard ad-flax (Comandra umbellata and ocaulon lividum), germinate and gin the next succession of spore tes on these plants, thus completing - life cycle of the fungus.

Cankers of the rust usually persist branches and trunks of pines for many years before growth of the rust around the stem kills the branch or tree, or the canker is inactivated. Some cankers have been found that were 100 years old and still growing. They may grow to a length of several feet. The centre or older portion of the canker is composed of cracked, rough dead bark tissues, killed by the rust.

Rust cankers provide a suitable habitat for the development of certain fungi and arthropods. Over a period of several years the fungi, bacteria, spiders, mites and insects found associated with the cankers and spores were collected and identified. Observations were made on the incidence of these organisms and their effect on cankers and on spore production. The incidence of rodent damage was also noted, for the swollen infected bark, which has a high concentration of sugars, is very attractive to rodents. The causes of canker inactivation were also recorded.

A total of 56 species of fungi and 8 bacteria was identified". A purple mold (Tuberculina maxima) (Fig. 2) and an undescribed dark green fungus (Cladosporium sp.) were most common and played an important role in reducing aeciospore production. The purple mold is parasitic on the rust canker and occurred on 20 to $55 \%$ of the active cankers depending on the year. It prevented spore production on 10 to $15 \%$ of the potential aecialproducing tissues in any one year and was the main cause for inactivation on about half the cankers ${ }^{3}$. Certain species of Cladosporium are parasitic on the aeciospores and occurred about

1. Aecial pustules (blisters) of the rust rupturing to release spores.

2. Canker infected with the purple mold (Tuberculina maxima) which is conspicuous as I darker area where the surface bark has been removed or cracked (see arrows).

2. 3. Typical rough bark of canker showing evidence of insect damage. Note exit holes ind Lepidoptera frass (refuse left by boring insects) at top of canker and further frass in ower rough zone (see arrows).

5. 4. Annual squirrel damage on a large canker. Note the strip of dried dead bark not removed each year, and the abundant exudation of resin. 


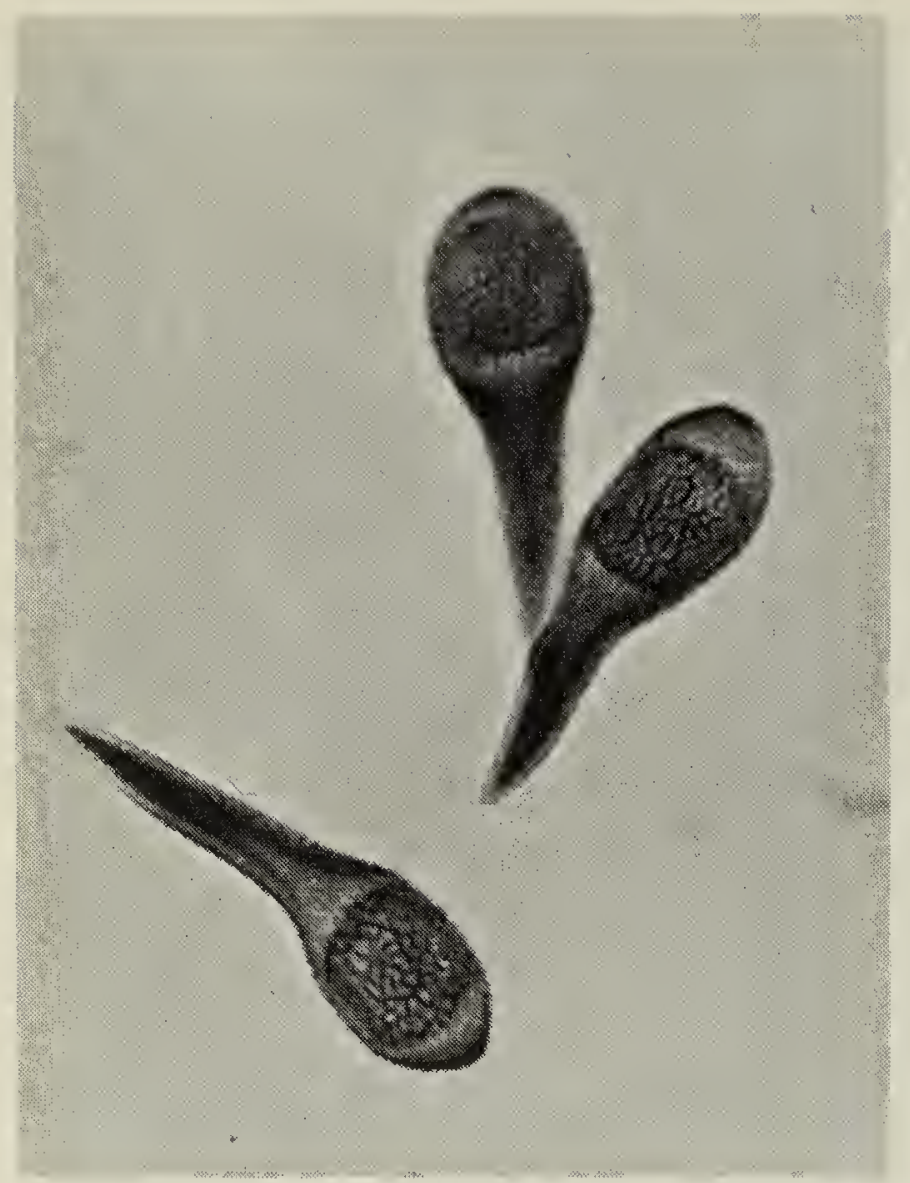

Fig. 5. Aeciospores with typical tail of species (magnified 650 times).

half as frequently as the purple mold. Several of the other fungi and bacteria, especially some Penicillium spp. Arthrobacter spp., Pseudomonas spp. and Rhodotorula spp., were componly found. These also affected aeciospore viability ${ }^{25}$.

A large number of arthropods were collected from the cankers, representing 143 species of insects, 19 mites and 4 spiders ${ }^{4} 7$. The insects damaged 41 to $62 \%$ of the cankers observed in any one year and reduced aeciospore production by $10 \%$ (Fig. 3). Three species appeared to depend exclusively on the host fungus for food during at least their larval stages. These were a nitidulid beetle (Epuraea obliquus), a cecidomyiid fly (Mycodiplosis sp.) and a drosophilid fly (Paracacoxenus guttatus). These species feed extensively on the spores but do little damage to the underlying infected bark tissue. Other species, notably the twig weevils (Cylindrocopturus deleoni and Pissodes schwarzi,
Fig: 6) and larvae of the cone moth (Dioryctria spp., Fig. 7, an Laspreyresia spp.), needleminer moth (Eucordylea spp.) and an olethreuti moth (Grapholitha sp.) fed among th spore masses and then mined exter: sively into bark tissues destroyin large areas of the aecial and sper mogonial zones of the canker. Other also did damage or fed on the spore but many of these could be classifier as only occasional visitors, no regularly associated with the rust.

Rodents caused extensive damage t the cankers through removal of th rust-infected bark down to the sap wood, usually in winter and spring although there was some chewin throughout the summer-and early fal In some areas there was extensiv damage every year, so that aeciospor production was minimal (Fig. 4) Squirrels, rabbits and hares wer responsible for most of this extensiv damage, although porcupines, chip munks and mice were also responsibl for some of the bark removal. Th rodents usually restricted their ac tivity, except in the case of porcupines to the infected bark, often removin all the spermogonial and some of th aecial zone, completely ringing the old portion of the canker. Often over $90 \%$ of the infected trees in a pine stanc have been scarred by rodent chewing Nearly 500 cankers were kept unde

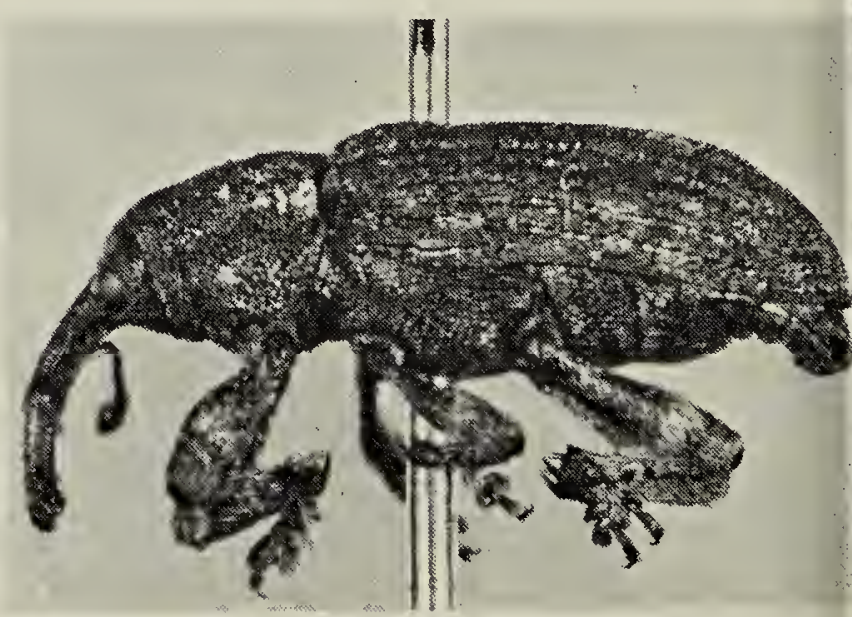

Fig. 6. Adult Pissodes schwarzi (side view length: $6 \mathrm{~mm}$.). 
